(C) 1982. The Genetical Society of Great Britain

\title{
INHERITANCE AND MAPPING OF STORAGE PROTEIN GENES IN PISUM SATIVUM L.
}

\author{
NARENDER K. MATTA* and JOHN A. GATEHOUSE. \\ Department of Botany, Durham University, South Road, Durham DH1 3LE, U.K.
}

Received 19.xi.81

\begin{abstract}
SUMMARY
One and two-dimensional sodium dodecyl sulphate polyacrylamide gel electrophoretic techniques have been used to follow the inheritance of legumin and convicilin subunits in crosses of various pea lines. The major legumin acidic subunits behaved as products of a single Mendelian gene with at least five different possible alleles. Independent segregation of a minor "big" legumin acidic subunit and the acidic and basic subunits of "small" legumin were observed, suggesting that while the main legumin subunits are produced from a set of closely linked genes at a single locus, further weakly expressed legumin genes are present at other loci. Convicilin subunits behaved as the products of a single Mendelian gene with at least three allelic forms. Genetic analysis of $F_{2}$ seeds and plants from crosses of pea lines was used to map the major legumin gene $(\mathrm{Lg}-1)$ to a locus near the $r-t l$ segment of chromosome 7 and the convicilin gene (Cvc) to a locus between $s$ and $k$ on chromosome 2.
\end{abstract}

\section{INTRODUCTION}

VARIATION in subunit band patterns of the storage proteins in Pisum sativum L., the garden pea, on gel electrophoresis has given rise to studies claiming that certain subunits of these proteins behave as single pairs of allelic genes in crossing experiments (Hynes, 1968; Thomson and Schroeder, 1978). However, the lack of good structural models for these proteins has hindered the interpretation of results, and only in the case of legumin has a clear confirmation of these claims been obtained through the detailed study of Casey (1979), although the minor legumin subunits were shown not to agree with the model. Linkage of the legumin gene to the $r$ locus on chromosome 7 has been demonstrated (Davies, 1980) but no accurate mapping of storage protein genes has been carried out.

Three major storage proteins may be defined. First, legumin, a protein containing six subunit pairs per approx. $400,000 \mathrm{Mr}$ molecule, each subunit pair containing a larger relatively acidic subunit and a smaller relatively basic subunit joined by one or more disulphide bonds (Wright and Boulter, 1974; Gatehouse et al., 1980). These subunit pairs may be divided into three types (Matta et al., 1981b): the main type (Mr 53,000-54,000) corresponds to the conventional legumin subunit pair of the Wright and Boulter (1974) model (the major legumin subunits of Casey, 1979), and the other two types (present in lesser amounts) have been designated "big" (Mr 55,000-58,000) and "small" (Mr 35,000) legumin subunit pairs. Legumin is synthesised as a precursor form, Mr approx. 60,000 in which the single polypeptide chain contains both an acidic and a basic subunit (Croy et al., 1980a), which are subsequently proteolytically cleaved. Secondly, vicilin, a protein of Mr 150,000 containing three approx.

* Present address: Department of Botany, University College, Kurukshetra-132119, India. 
$50,000 \mathrm{Mr}$ subunits as synthesised, some of which are subsequently proteolytically cleaved to generate polypeptides of smaller Mr (Croy et al., $1980 \mathrm{~b}$; Gatehouse et al., 1981); and thirdly, convicilin, a protein of Mr 280,000 containing only subunits of approx. 70,000 Mr (Croy et al., $1980 c$ ), which do not appear to undergo extensive post-translational modification.

Variations in the SDS-polyacrylamide gel electrophoretic band patterns of the legumin and convicilin proteins have provided the basis for the present study, which has attempted to characterise and map the genetic loci responsible for their synthesis.

\section{MATERIALS AND METHODS}

\section{(i) Plant materials}

Seeds of different pea lines and $\mathrm{F}_{2}$ seeds of various crosses were supplied by Dr S. Blixt, Weibullsholm Plant Breeding Institute, Landskrona, Sweden. Crosses of lines $1238 \times 1263,110 \times 807$ and $110 \times 851$ were carried out in Durham: all other crosses were carried out by Dr Blixt. Developing seeds were allowed to mature completely on greenhouse grown plants before analysis.

Genotypes of the pea lines used were as follows:

$110 \quad a, t d, D^{c o}, N p, t e, P l, M, F, F s$

$807 K p, D^{m a}, M$

$851 P a, v i m, b, k, d t, p r, w b, t l^{w}, s t, t d, D^{c o}, f$, pro, le, di, mifo, s, oh, cor, $F, F s, i, r$

$1238 b, k, B r a, d t, p r, w b, t l^{w}, d, f l, f r, f r u, p r o, c o h, l e, t, c p-1, t e, g p$, pur ${ }^{a}$, sru, $s, U^{s t}, i, r$

$1263 a, B r, d t$, Tra

$1293 K p, K p a, t d, D^{c o}, D p o, n, N p$, cotr, te, rup, rups, sru, srub, Gty, Him, Pl, Fs, $U^{s t}$

All these lines except 1293 are known to be of normal karyotype. The karyotype of line 1293 is not established.

\section{(ii) Chemicals}

Chemicals used were obtained from BDH Ltd. except as noted, and were of the highest grade available. Trizma base (Tris (Hydroxymethyl) aminomethane) was from Sigma Chemical Co.

\section{(iii) Methods}

SDS-polyacrylamide gel electrophoresis (SDS-PAGE) was carried out in 12.5 per cent acrylamide gels by the method of Laemmli (1970). Twodimensional SDS-PAGE with non-reducing conditions in the first dimension and reducing conditions in the second dimension was performed 
as described by Matta et al. (1981a). Extracts from single pea seeds for SDS-PAGE were prepared as follows:

A piece of cotyledon tissue was removed from the dry seed, taking care to avoid damaging the embryonic axis, and separated from any adhering testa. The cotyledon tissue was then finely ground in a small mortar and pestle, and the meal extracted by shaking overnight at $4^{\circ} \mathrm{C}$ with sample buffer $(40 \mathrm{mg} \mathrm{meal} / \mathrm{ml} \mathrm{SDS}-P A G E$ sample buffer), centrifuged at $9000 \mathrm{~g}$ for $5 \mathrm{~min}$, and the supernatant $(10 \mu \mathrm{l})$ taken for loading onto gels. $R / r$ phenotypes were determined by examination of starch grains, and by observation of the phenotypes of $F_{3}$ seeds.

The statistical methods used were those of Fisher (1925) for calculating $X^{2}$ values, and those of Immer (1930) ("product ratio" method) for calculating percentages of crossing over and probable errors. In the latter method one of the co-dominant factors in the allelic pair was considered as dominant so that in a dihybrid cross involving dominant and co-dominant factors, the factors were in a coupling phase.

\section{(iv) Nomenclature}

The gene symbols used in this paper have been reformulated in accordance with the recommendations of the Pisum Genetics Association (Blixt, 1972; Blixt, 1977).

(a) Legumin: Lg. Legumin acidic and basic subunits (gene products) are referred to as $\alpha$ and $\beta$ respectively: "conventional", "big" and "small" legumin subunit pairs are referred to as Lg-1, Lg-2 and $\mathrm{Lg}-3$ respectively. Thus $\mathrm{Lg}-1 \alpha$ refers to the acidic subunits(s) of "conventional" legumin subunit pairs, etc.

(b) Vicilin: Vc

(c) Convicilin: Cvc

Wherever possible these symbols have been related to those previously used. Since the number of variant alleles at these loci is not known, subunits that vary between pea lines are referred to thus: $\mathrm{Lg}-1 \alpha^{(110)}, \mathrm{Lg}-1 \alpha^{(807)}$, where $\operatorname{Lg}-1 \alpha^{(110)}$ refers to the acidic subunit band (or spot) pattern of conventional legumin of line 110 and $\mathrm{Lg}-1 \alpha^{(807)}$ refers to the different acidic subunit band (or spot) pattern of conventional legumin of line 807 . Additive band patterns are designated thus: $\mathrm{Lg}-1 \alpha^{(110+807)}$. These symbols are intended as a working system and have no theoretical justification in terms of actual genes.

\section{Results}

\section{(i) Inheritance of legumin subunits}

The inheritance of legumin subunits was studied in the cross of lines 110 and 807 . Legumin subunits were identified by running total protein extracts of single seeds of the parental lines on non-reducing/reducing two dimensional SDS-PAGE (fig. 1) where they appeared as spots "off the 
diagonal" of non-reducible protein subunits. The subunits identified were as follows:

\begin{tabular}{|c|c|c|c|c|}
\hline \multirow[t]{2}{*}{$\begin{array}{l}\text { Subunit } \\
\text { type }\end{array}$} & \multicolumn{2}{|c|}{ Pisum line 110} & \multicolumn{2}{|c|}{ Pisum line 807} \\
\hline & coded as & $\mathbf{M r}$ & coded as & $\mathbf{M r}$ \\
\hline $\mathrm{Lg}-2 \alpha$ & C: $\operatorname{Lg}-2 \alpha^{(110)}$ & $\left\{\begin{array}{l}43,000 \\
40,000 \\
38,000\end{array}\right.$ & D: $\operatorname{Lg}-2 \alpha^{(807)}$ & $\left\{\begin{array}{c}43,000 \\
\text { (absent) } \\
38,000\end{array}\right.$ \\
\hline $\operatorname{Lg}-1 \alpha$ & A: $\operatorname{Lg}-1 \alpha^{(110)}$ & 35,500 & B: $\operatorname{Lg}-1 \alpha^{(807)}$ & $\left\{\begin{array}{l}37,500 \\
35,500 \\
35,000\end{array}\right.$ \\
\hline $\operatorname{Lg}-3 \alpha$ & $\left\{\mathrm{R}: \mathrm{Lg}-3 \alpha^{(110)}\right.$ & 24,500 & $S: \operatorname{Lg}-3 \alpha^{(807)}$ & $\left\{\begin{array}{l}25,000 \\
24,500\end{array}\right.$ \\
\hline $\mathrm{Lg}-1 \beta$ & & 22,700 & & 22,700 \\
\hline $\mathrm{Lg}-2 \beta$ & & $22,300-21,300$ & & $22,300-21,300$ \\
\hline $\mathrm{Lg}-3 \beta$ & $\left\{\mathrm{X}: \operatorname{Lg}-3 \beta^{(110)}\right.$ & $\left\{\begin{array}{l}21,000 \\
20,700\end{array}\right.$ & $Y: \operatorname{Lg}-3 \beta^{(807)}$ & $\left\{\begin{array}{l}21,300 \\
20,700\end{array}\right.$ \\
\hline
\end{tabular}

$\mathrm{Lg}-1 \alpha^{(110)}$ and $\mathrm{Lg}-1 \alpha^{(807)}$ are products of subunit pair $\mathrm{Lg}-1$ representing the conventional legumin subunit pair ( $\mathrm{Mr} 53,000)$, which on reduction gave rise to two groups of subunits. The acidic subunits in line 110 consisted of only one band of Mr 35,500 (Pattern A) but those of line 807 gave three bands of Mr 37,400, 35,500 and 35,000 (Pattern B). (See fig. 1.) Electrofocusing studies followed by SDS-polyacrylamide gel electrophoresis showed that the band in line 110 actually consisted of two subunits and that the three bands of line 807 consisted of one subunit each.

$\mathrm{Lg}-2 \alpha^{(110)}$ and $\mathrm{Lg}-2 \alpha^{(807)}$ were taken as products of subunit pairs of $\mathrm{Mr}$ higher than that of conventional legumin. Both lines produced bands of $\mathrm{Mr} 57,000$ under non-reducing conditions (fig. 2) which gave rise to $\mathrm{Lg}-2 \alpha$ subunits of $\mathrm{Mr} 43,000$ and 38,000 and $\mathrm{Lg}-2 \beta$ subunits of $\mathrm{Mr} 21,300-$ 22,300 when reduced. However, a band of $\mathrm{Mr} 55,000$ was present in the line 110, but was not clearly apparent in the line 807 under non-reducing conditions. Two dimensional electrophoresis showed that this subunit pair on reduction gave rise to an $\mathrm{Lg}-2 \alpha$ subunit of $\mathrm{Mr} 40,000$ and $\mathrm{Lg}-2 \beta$ subunit of $\mathrm{Mr} 22,000$ and that it was present in line 110 but absent from line 807 . Only the $\mathrm{Lg}-2 \alpha$ (acidic) subunit was clearly analysed and studied. The presence of this subunit was described as pattern $C$ and its absence as pattern D (fig. 1).

$\mathrm{Lg}-3 \alpha^{(110)}$ and $\mathrm{Lg}-3 \alpha^{(807)}$ and $\mathrm{Lg}-3 \beta^{(110)}$ and $\mathrm{Lg}-3 \beta^{(807)}$ were taken as products of subunit pairs of smaller $\mathrm{Mr}$ than that of conventional legumin (Matta et al., 1981b). The acidic and basic subunits differed in their pattern in two lines. In line 110 there was a single acidic subunit, $\mathrm{Mr}$ 24,500 (Pattern R) whereas in line 807 two acidic subunits, Mr 25,000 and 24,500 (Pattern S) were observed. The basic subunits also differed in that although each line gave spots on two dimensional gels (fig. 1), those of line 110 were at Mr 21,000 and 20,700 (Pattern X) and those of line 807 were at Mr 21,300 and 20,700 (Pattern Y).

As a working hypothesis the variant subunit patterns noted were assumed to be the products of allelic forms of four genes, $\mathrm{Lg}-1 \alpha, \mathrm{Lg}-2 \alpha$, $\mathrm{Lg}-3 \alpha$ and $\mathrm{Lg}-3 \beta$. The inheritance of each of these genes was then studied. 


\section{Plate I}

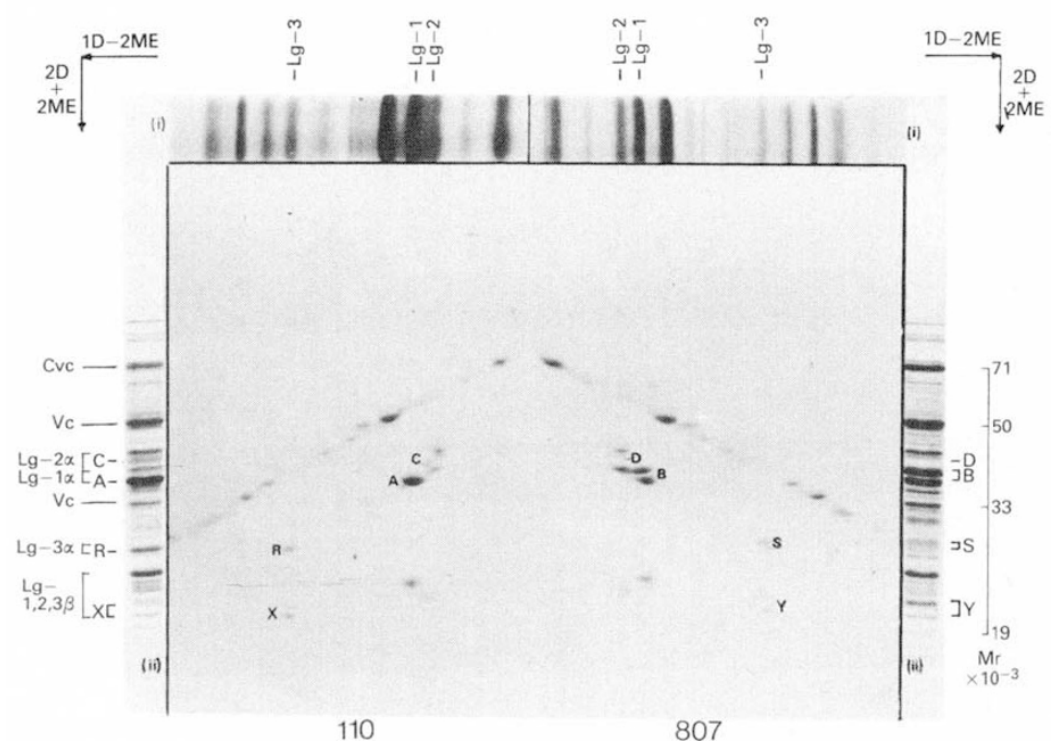

FIG. 1(a).-Two dimensional SDS-polyacrylamide gel electrophoresis of total protein extracts of Pisum lines 110 and 807. 1D: electrophoresis under non-reducing conditions in the first dimension: band patterns shown in tracks (i). 2D: electrophoresis under reducing conditions in the second dimension: band patterns shown in tracks (ii). $\mathrm{Lg}, \mathrm{Cvc}$ and $\mathrm{Vc}$ are used to identify legumin, convicilin and vicilin polypeptides as defined. Letters, $\mathrm{A}$, B, C, D, R, S, X, Y are used to iden tify variant subunits as follows: Pattern A: Lg-1 $\alpha^{(110)}$, Pattern B: Lg-1 $\alpha^{(807)}$, Pattern C: Lg- $\alpha^{(110)}$, Pattern D: Lg- $2 \alpha^{(807)}{ }^{(8 t)}$ Pattern R: Lg-3 $\alpha^{(110)}$, Pattern S: $\operatorname{Lg}-3 \alpha^{(807)}$, Pattern X: Lg-3 ${ }^{(110)}$, Pattern Y: Lg-3 $\beta^{(803)}$.

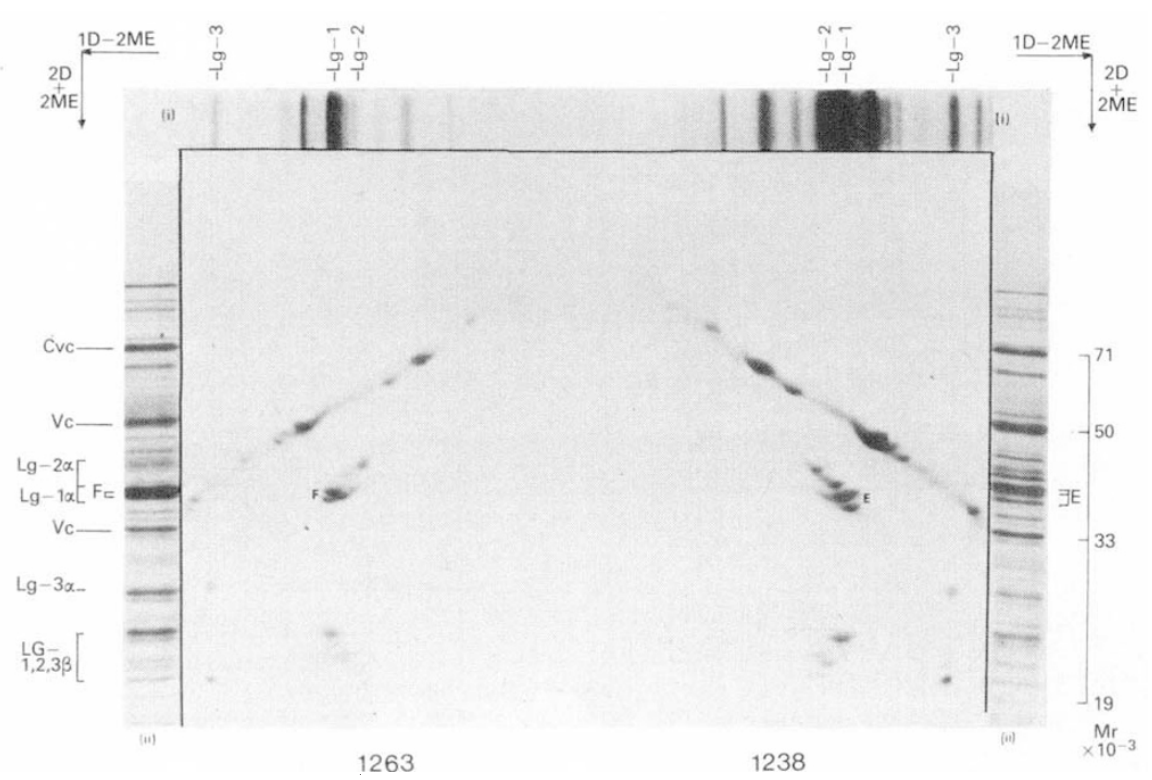

FIG. 1(b).-Two dimensional SDS-polyacrylamide gel electrophoresis of total protein extracts of pea lines 1263 and 1238. 1D: electrophoresis under non-reducing conditions in the first dimension: band patterns shown in tracks (i). 2D: electrophoresis under reducing conditions in the second dimension: band patterns shown in tracks (ii). $\mathrm{Lg}, \mathrm{Cvc}$ and Vc are used to identify legumin, convicilin and vicilin polypeptides as defined. Letters E, F are used to identify variant subunits as follows: Pattern E: Lg-1 $\alpha^{(1238)}$, Pattern F: are used 12631 


\section{Plate II}

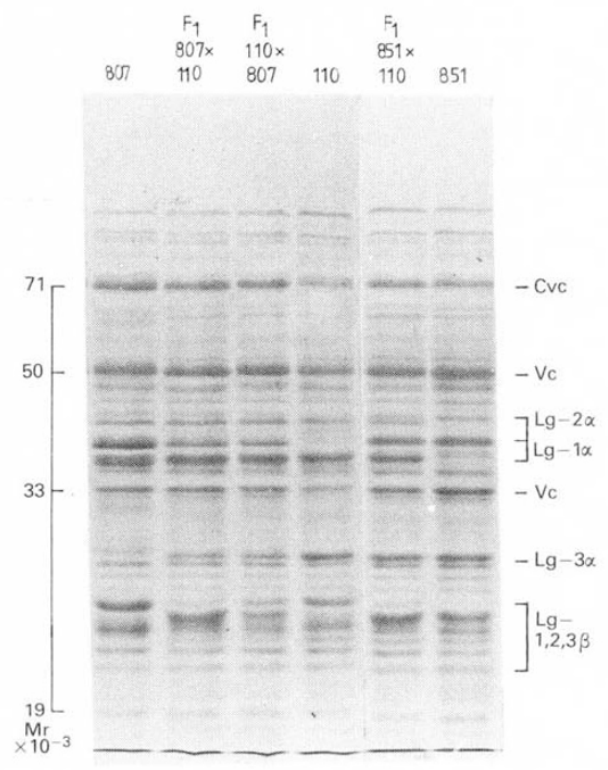

(a)

$F_{1}$

$F_{1}$

$1263(1238 \times 1263) \quad 1238 \longmapsto(1263 \times 1238) \longrightarrow 1263$

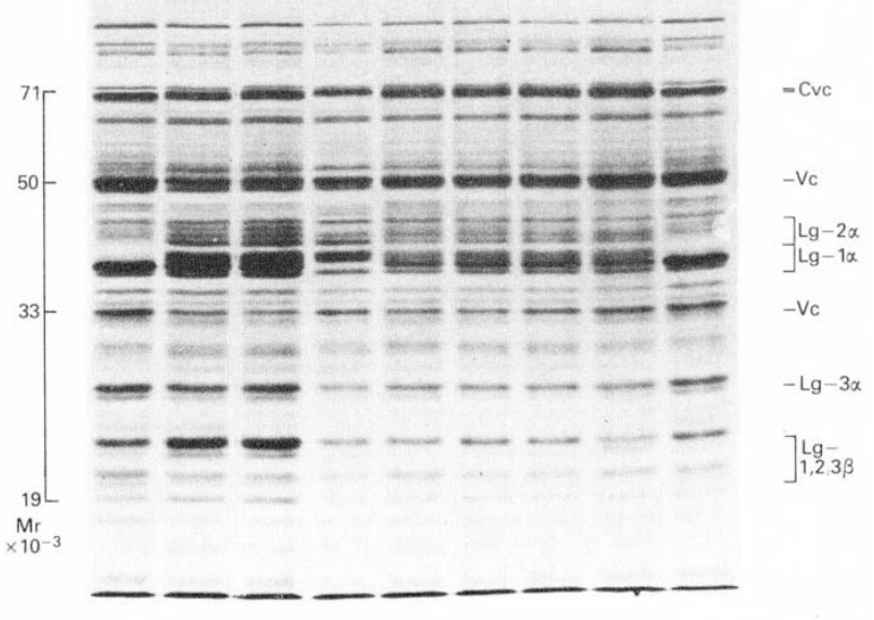

(b)

FIG. 2.-SDS-polyacrylamide gel electrophoresis (reducing conditions) of: (a) the total protein extracts of Pisum parental lines 110,807 and 851 and F1 seeds of the reciprocal crosses between them: (b) the total protein extracts of Pisum parental lines 1238 and 1263, and the $F 1$ seeds of the reciprocal cross between them. 
$F_{1}$ seeds from the cross of lines $110 \times 807$ showed a band pattern on SDS-PAGE which was the sum of the band patterns of the two parental lines, and was the same in reciprocal crosses (fig. 2). $F_{1}$ plants were allowed to produce selfed $F_{2}$ seed. 170 such seeds were analysed by SDS-PAGE, and a further 52 seeds were analysed by two-dimensional gel electrophoresis. In all cases the observed band patterns at each of the variant alleles was either that of one parent or the other, or a combination. (Variation at the Lg-2 (C/D) locus was ascribed to a dosage effect, i.e., Lg-2 $\alpha$ band at $\mathrm{Mr} 40,000$ distinctly present or absent, $\mathrm{F}_{2}$ homozygous: band weakly present, $F_{2}$ heterozygous.) Band patterns of the subunits which did not vary between lines 110 and 807 showed no variation in $F_{1}$ or $F_{2}$ seeds. The observed segregations at each of the variant patterns $\mathrm{Lg}-1 \alpha$, $\operatorname{Lg}-2 \alpha, \mathrm{Lg}-3 \alpha$ and $\operatorname{Lg}-3 \beta$ were in agreement with each of these being controlled by a single pair of co-dominant alleles (table 1 ). Various combinations of the patterns $\mathrm{Lg}-1 \alpha, \mathrm{Lg}-2 \alpha, \mathrm{Lg}-3 \alpha$ and $\mathrm{Lg}-3 \beta$ were also tested for independent assortment (data not presented). A statistically significant chi-square value showing a considerable degree of linkage was found only between the genes controlling the $\mathrm{Lg}-2 \alpha$ and $\mathrm{Lg}-3 \beta$ patterns: no other subunits showed linkage. These results are illustrated in fig. 3(a).

Results from the cross of lines $1238 \times 1263$ (fig. 2(b), table 1) were in full agreement with those given above except that in this case no segregation

TABLE 1

Analysis of $F_{2}$ segregation of various legumin and convicilin subunit patterns and their chi-square values

(a) Cross $110 \times 807$

\begin{tabular}{|c|c|c|c|c|}
\hline Subunit & (110) & $\begin{array}{l}\text { Frequency of the segregating } \\
\text { patterns in } F_{2} \text { generation } \\
\qquad(110+807)\end{array}$ & (807) & $\chi^{2}(n=2)$ \\
\hline $\begin{array}{l}\text { Lg-1 } \alpha \\
\text { Observed } \\
\text { Expected }\end{array}$ & $\begin{array}{l}48 \\
42 \cdot 5\end{array}$ & $\begin{array}{l}84 \\
85\end{array}$ & $\begin{array}{l}38 \\
42 \cdot 5\end{array}$ & 1.2 \\
\hline $\begin{array}{l}\operatorname{Lg}-2 \alpha \\
\text { Observed } \\
\text { Expected }\end{array}$ & $\begin{array}{l}43 \\
42.5\end{array}$ & $\begin{array}{l}92 \\
95\end{array}$ & $\begin{array}{l}35 \\
42 \cdot 5\end{array}$ & 1.9 \\
\hline $\begin{array}{l}\operatorname{Lg}-3 \alpha \\
\text { Observed } \\
\text { Expected }\end{array}$ & $\begin{array}{l}15 \\
13\end{array}$ & $\begin{array}{l}20 \\
26\end{array}$ & $\begin{array}{l}17 \\
13\end{array}$ & 2.92 \\
\hline $\begin{array}{l}\text { Lg-3 } \beta \\
\text { Observed } \\
\text { Expected }\end{array}$ & $\begin{array}{l}10 \\
13\end{array}$ & $\begin{array}{l}26 \\
26\end{array}$ & $\begin{array}{l}16 \\
13\end{array}$ & $1 \cdot 38$ \\
\hline
\end{tabular}

(b) Cross $1238 \times 1263$

$(1238+1263)$

Lg-1 $\alpha$

Observed

Expected

Convicilin

Observed 
between $\operatorname{Lg}-1 \alpha$ and $\mathrm{Lg}-2 \alpha$ subunits was observed. The $\mathrm{F}_{2}$ segregation is illustrated in fig. 3(b).

\section{(ii) Mapping of the Lg-1 locus}

Reciprocal crosses were made between lines 1238 and 1263 in order to assign the legumin gene $\mathrm{Lg}-1 \alpha$ to a particular linkage group. Besides differing in a number of genetic characteristics (see earlier), the two lines differed in the pattern of $\mathrm{Lg}-1 \alpha$ subunits and convicilin subunits. $\mathrm{Lg}-1 \alpha$ subunits were represented by three bands of $\mathrm{Mr} 38,000,37,000$ and 35,000 in the line $1238\left(\mathrm{Lg}-1 \alpha^{(1238)}\right.$ : pattern $\mathrm{E}$ ) and by two bands (in onedimensional gels) of $\mathrm{Mr} 35,500$ and 35,000 in the line $1263\left(\mathrm{Lg}-1 \alpha^{(1263)}\right.$ : pattern F (Fig. 1(b)).

To establish whether the genes for the acidic subunits of legumin and the genes for the selected morphological markers were linked, $F_{1}$ plants were backcrossed with line 1238 . The phenotypes of 19 plants were determined which showed that the $\mathrm{Lg}-1 \alpha$ gene appeared to be linked with $t l-r$ segment of chromosome 7 . Two plants showed recombination between Lg- 1 and $t l$ (presence or absence of tendrils) and four plants were recombinants between $\mathrm{Lg}-1 \alpha$ and $r$ (seeds round or wrinkled). A higher number of recombinants between $\mathrm{Lg}-1 \alpha$ and $r$ genes points towards the location of $\mathrm{Lg}-1 \alpha$ gene being on the side of $t l$ locus away from $r$ locus.

This location was further investigated by determining the phenotypes of $F_{2}$ plants in crosses of lines $1238 \times 1263$ and $1238 \times 1293$ for which the data are presented in tables 2 and 3 . In both cases linkage of the $\mathrm{Lg}-1 \alpha$ gene to $t l$ and $r$ was established, but the crossover values obtained varied considerably. To fix the $\mathrm{Lg}-1 \alpha$ gene position, a cross was thus carried out between lines 110 and 851 . In this case linkages to the genes pa, (foliage colour) $t l$ and $r$ on chromosome 7 could be estimated (table 3 ), and analysis of $46 \mathrm{~F}_{2}$ seeds and plants showed that $\mathrm{Lg}-1 \alpha$ was located on the side of

the $t l-r$ segment opposite to $p a$. The mean crossover values obtained from the three crosses indicated that $\mathrm{Lg}-1 \alpha$ was located 17 map units from $r$ and 10 map units from $t l$.

\section{(iii) Inheritance and mapping of the convicilin gene (Cvc)}

The convicilin subunits at $\mathrm{Mr}$ approx. 70,000 showed slight variation in lines 1238 and 1263 , the band in line $1238\left(\mathrm{Cvc}^{(1238)}\right)$ being at slightly higher apparent $\mathrm{Mr}$ on SDS-PAGE than the band in line 1263 (Cvc ${ }^{1263)}$ ) as shown in fig. 2 . Two very closely spaced bands, i.e., an additive pattern, $\mathrm{Cvc}^{(1238+1263)}$, were shown by $\mathrm{F}_{1}$ seeds from the cross $1238 \times 1263$ with either line as female parent (fig. 2). The band patterns $\mathrm{Cvc}^{(1238)}: \mathrm{Cvc}^{(1238+1263)}: \mathrm{Cvc}^{(1263)}$ followed a 1:2:1 segregation in $\mathrm{F}_{2}$ seeds from $1238 \times 1263$ (table 1) and thus were controlled by a single pair of codominant alleles. Cvc band patterns were inherited independently from the $\mathrm{Lg}-1 \alpha$ band patterns $\left(\chi_{(8)}^{2}=5 \cdot 06\right.$, and see fig. $\left.3(\mathrm{~b})\right)$, but were strongly linked to the keel type in flowers and the presence or absence of tragacanth excretion in seeds, i.e., genes $k$ and $s$ on chromosome 2. The crossover values deduced are given in table 2; these data support a location for Cvc between $s$ and $k$, approximately 3 map units from $k$. 


\section{Plate III}

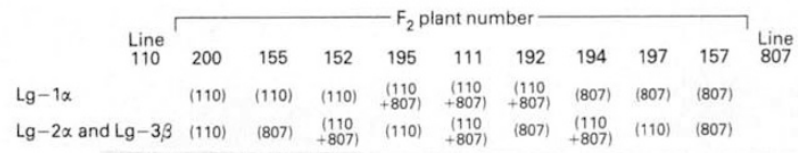

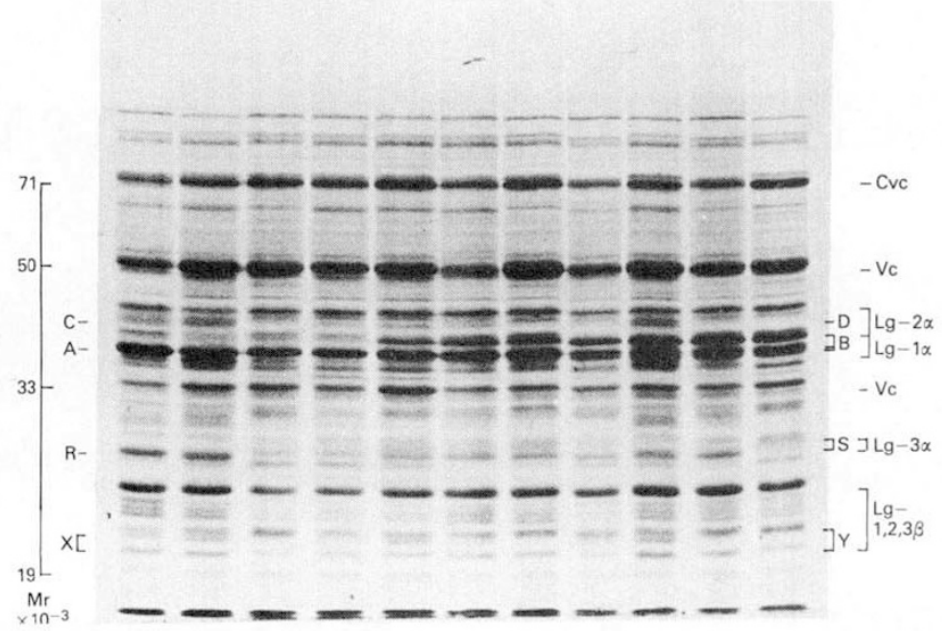

(a)

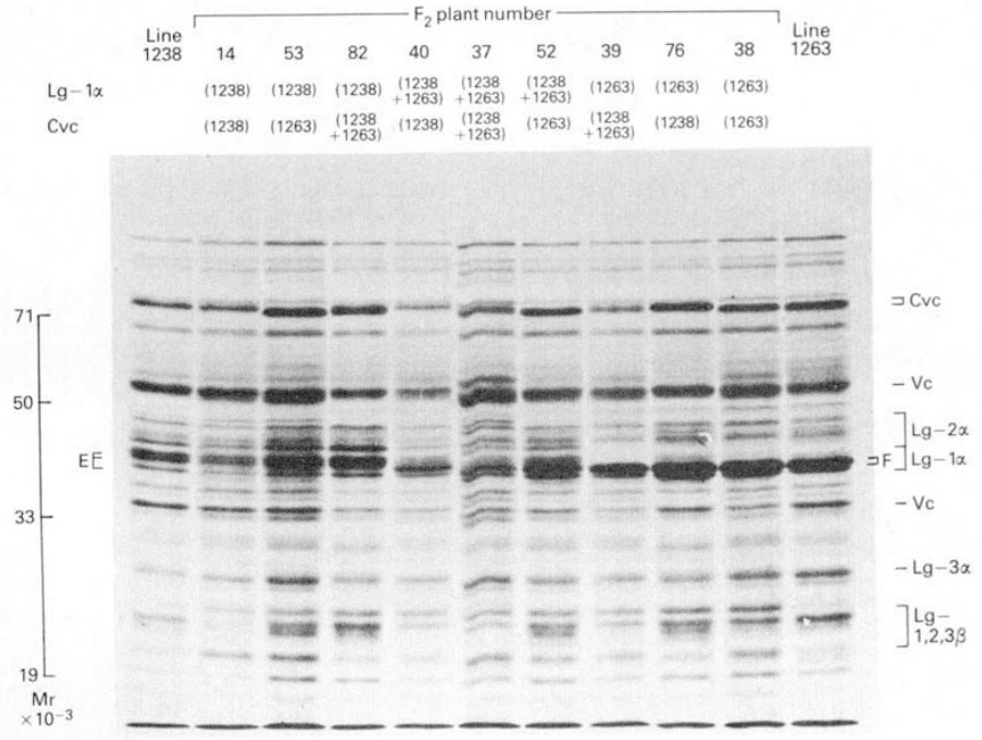

(b)

FIG. 3.-SDS-polyacrylamide gel electrophoresis, under reducing conditions, cf: (a) total protein extracts showing different combinations of $\mathrm{Lg}-1 \alpha$ and $\mathrm{Lg}-2 \alpha, \mathrm{Lg}-3 \beta$ in $\mathrm{F}_{2}$ plants of the cross between Pisum lines $110 \times 807$ : (b) total protein extracts showing different combinations of $\mathrm{Lg}-1 \alpha$ and $\mathrm{Cvc}$ in $\mathrm{F}_{2}$ plants of the cross between Pisum lines $1238 \times 1263$. Lg- $1 \alpha$ phenotype assignments distinguishing $(110+807)$ from $(807)$ in fig. 3(a) were made on the basis of relative intensities of stained bands at Mr 35,500 and 35,000 on the original gel, which are not clear here. 


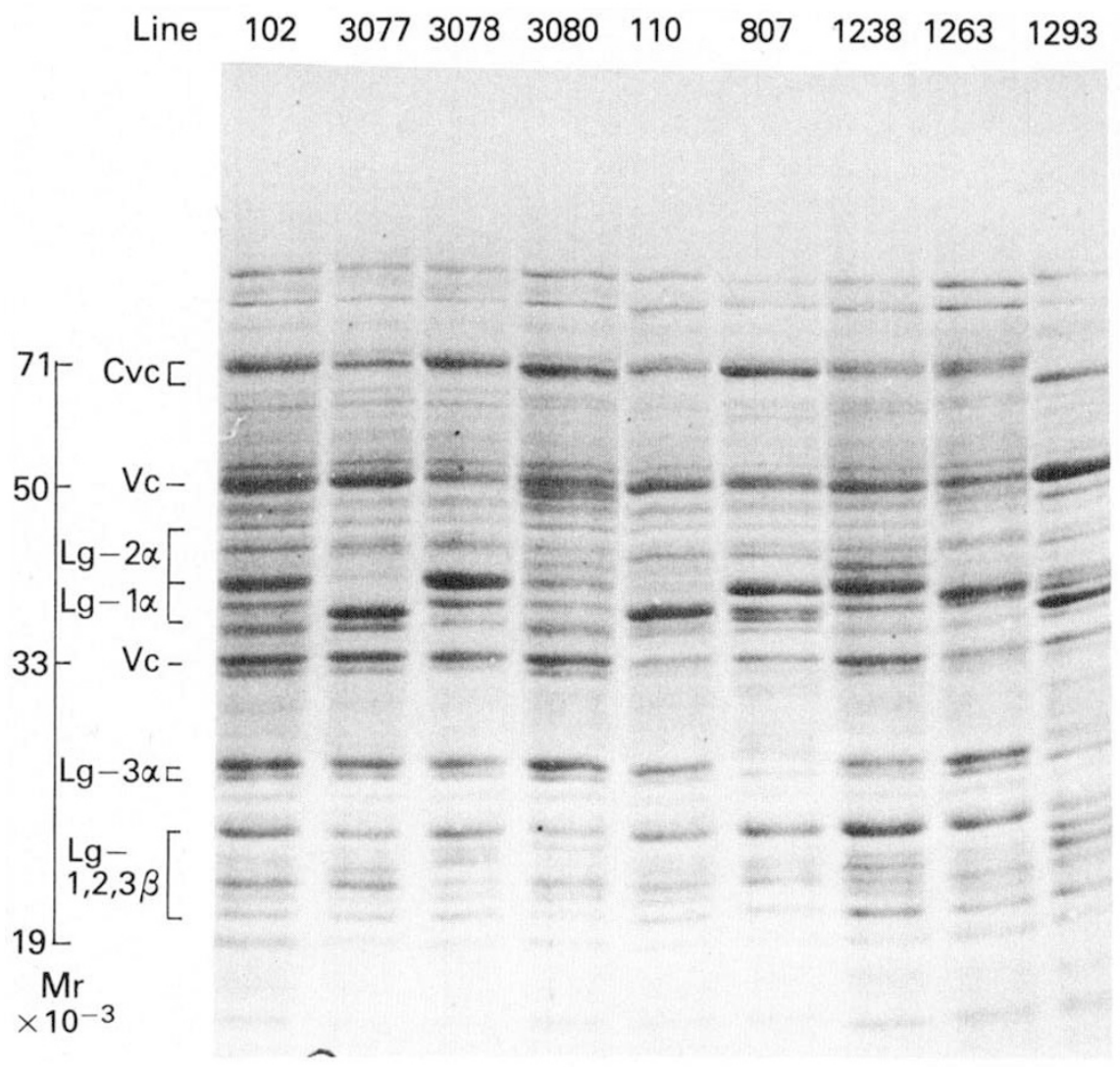

FIG. 4,-SDS-polyacrylamide gel electrophoresis, under reducing conditions, of total protein extracts of various lines of Pisum. Lines 102, 3077, 3078, and 3080 are type lines for the genes defined by Thomson and Schroeder (1978) as follows: $102: \mathrm{VB}^{\mathrm{B}} \mathrm{VC}^{\mathrm{B}}, 3077$ : $\mathrm{LA}^{\mathrm{A}} \mathrm{LC}^{\mathrm{A}}, 3078: \mathrm{LA}^{\mathrm{B}} \mathrm{LC}^{\mathrm{B}} \mathrm{VA}^{\mathrm{A}} \mathrm{VB}^{\mathrm{A}}, 3080: \mathrm{VA}^{\mathrm{B}} \mathrm{VC}^{\mathrm{A}}$. 


\section{Plate $V$}

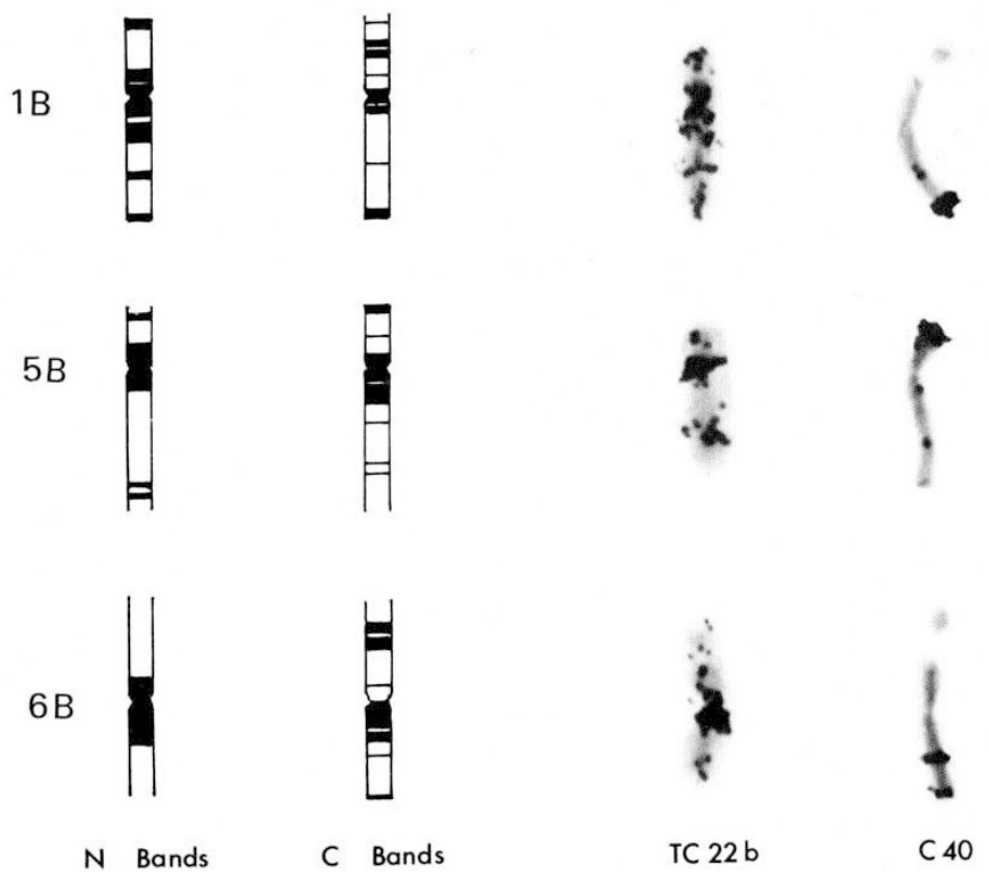

FIG. 5.-Comparisons of the $\mathrm{C}$-banding and $\mathrm{N}$-banding patterns of chromosomes $1 B, 5 B$ and $6 B$ with the distributions of the highly repetitive sequences from TC22b and $\mathrm{C} 40$ in these chromosomes. Photographs of the labelling patterns of the probes on typical chromosomes are shown. The chromosomes could be readily identified by the presence of satellites in chromosomes $1 B$ and $6 B$ and by the arm ratio of chromosome $5 B$, as well as by examination of the labelling patterns of marked telocentric stocks. The N-banding pattern karyotype is taken from Gerlach (1977) and the C-banding karyotype from Gill and Kimber (1974). 


\section{Plate VI}

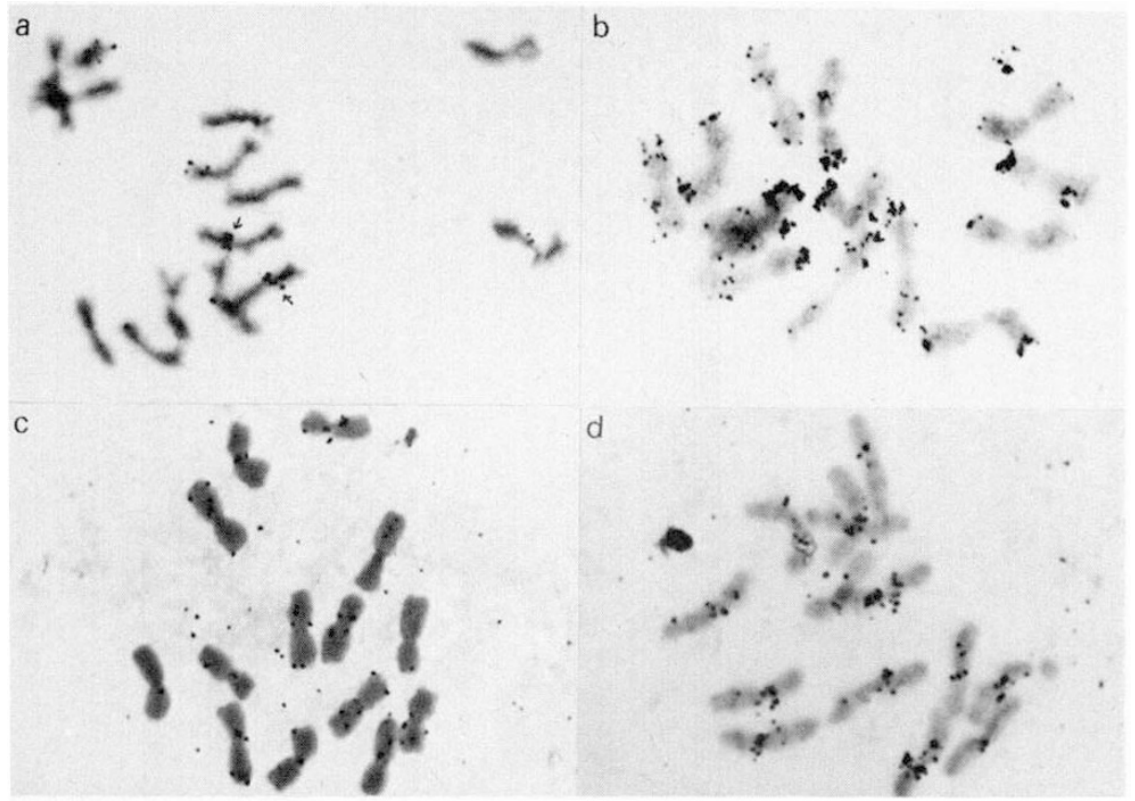

FIG. 6.-In situ hybridisation of the wheat highly repetitive sequence probes to the chromosomes of rye and barley. (a) S. cereale cv. Petkus Spring with probe TC22b. (b) S. cereale cv. Petkus Spring with probe C40. (c) H.vulgare cv. Sundance with probe C40. (d) $H$. vulgare cv. Sultan with probe TC22b. 


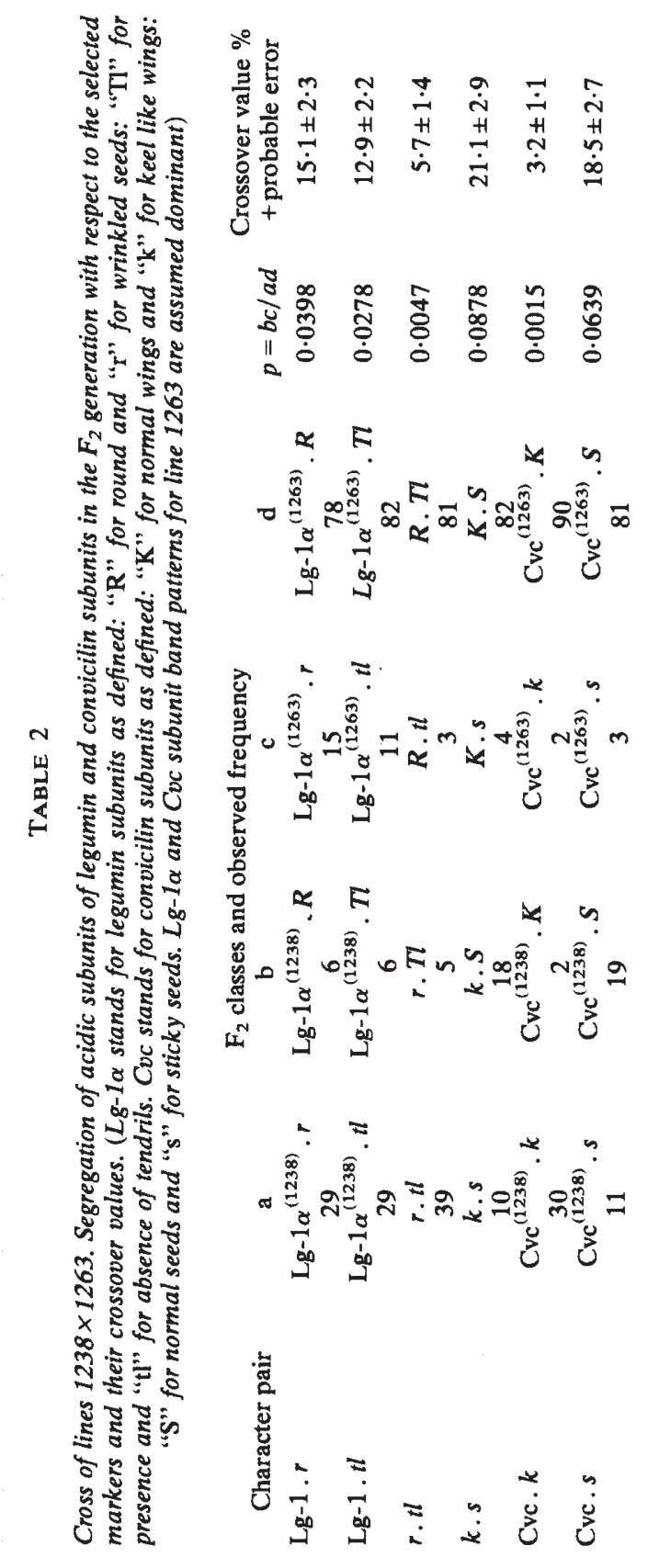


TABLE 3

Crossover values obtained between genes on chromosome 7 in crosses of various pea lines

$\begin{array}{lccr}\begin{array}{l}\text { Cross } \\ \text { (No of plants) }\end{array} & \begin{array}{c}1238 \times 1263 \\ (128)\end{array} & 1238 \times 1293 & 110 \times 851 \\ \text { Crossover } & & & (46) \\ \text { value between } & & & \\ \mathrm{Lg}-1 \alpha / r & 15 \cdot 1 \pm 2 \cdot 3 & 22 \cdot 5 \pm 3 \cdot 1 & 14 \cdot 4 \pm 3 \cdot 8 \\ \mathrm{Lg}-1 \alpha / t l & 12 \cdot 9 \pm 2 \cdot 2 & 7 \cdot 0 \pm 1 \cdot 8 & 8 \cdot 0 \pm 3 \cdot 0 \\ \quad r / t l & 5 \cdot 7 \pm 1 \cdot 4 & 11 \cdot 9 \pm 2 \cdot 5 & 0^{*} \\ \mathrm{Lg}-1 \alpha / p a & - & - & 30^{\dagger} \\ \quad \text { * No recombinants found. } & & & \\ \quad & & \end{array}$

Data from $F_{2}$ seeds of the cross $1238 \times 1293$ supported this conclusion in that a linkage value of $18.1 \pm 4.0$ per cent between Cvc and $w b$ (waxless foliage) was obtained. In this case line 1293 showed a more marked variation in convicilin band position (fig. 4).

\section{Discussion}

The results presented in this paper have extended the results of Davies (1980) and accurately located the major legumin gene, here designated $\mathrm{Lg}-1 \alpha$, on chromosome 7 in pea. This gene is equivalent to that designated LA by Thomson and Schroeder (1978) as shown in the type lines 3077 and 3078 (fig. 4) and is also equivalent to that responsible for the $\alpha M$ legumin acidic subunits of Casey (1979). The synthesis of legumin as a precursor containing a complete acidic and basic subunit (Croy et al., $1980 a$ ) then implies that the basic subunit gene (designated $\mathrm{Lg}-1 \beta$ here) is not an independent entity. We have not observed any variation in the band pattern of the major legumin basic subunits, in a large number of pea lines, apart from that due to storage effects (Matta and Gatehouse, 1981), so that it has not been possible to check that the major acidic and basic subunits are not independently inherited. However, we propose the simple term Lg-1 be used for this locus which putatively gives rise to all the major legumin subunits. The observed subunit heterogeneity would suggest the presence of a limited number of legumin genes in a closely linked array at the Lg-1 locus, since the multiple subunits behave as products of a single gene in crossing experiments. At least five different band patterns have been observed for the major acidic subunits of legumin in different pea lines (Croy et al., 1979; Casey, 1979; Matta, unpublished results), indicating that multiple alleles are possible at this locus.

Independent segregation of minor legumin acidic subunits, as observed in this study in the cross of lines 110 and 807 and designated $\operatorname{Lg}-2 \alpha$, is equivalent to the variation of $\alpha \mathrm{m}$ legumin subunits reported by Casey (1979) and possibly the locus designated LB by Thomson and Schroeder (1978) and suggests the presence of one or more weakly expressed legumin genes at other chromosomal locations than the Lg-1 locus. However, the results from the cross $1238 \times 1263$ where no independent segregation of $\mathrm{Lg}-1 \alpha$ and $\mathrm{Lg}-2 \alpha$ subunits was observed shows that these minor legumin acidic subunits are also products of genes at (or very close to) the Lg-1 
locus. This would allow segregation between $\mathrm{Lg}-2 \alpha$ subunits, as apparently observed by Casey (1979). These minor legumin subunits seem likely to be derived from precursors very similar to the precursors to the major legumin subunits.

Variation in the acidic and basic subunits of "small legumin" (here designed $\operatorname{Lg}-3 \alpha$ and $\mathrm{Lg}-3 \beta$ ) is apparently equivalent to the subunits of Casey (1979) (acidic subunits) and to the loci designated LD (basic subunits) and LE (acidic subunits) by Thomson and Schroeder (1978). Since no scheme to explain the derivation of these polypeptides from appropriate precursors is available, interpretation of results concerning "small legumin", especially in relation to the apparent independent segregation of its acidic and basic subunits, is impossible.

The mapping of the convicilin gene at a locus close to $k$ on chromosome 2 of pea shows that the storage protein genes are not "clustered" on the pea genome, in agreement with the observation of Casey and Sanger (1980) that legumin and convicilin loci were not linked. Since the patterns of accumulation of convicilin and legumin during seed development are similar (unpublished results), this implies independent but similar control elements for the two genes, both of which respond in a similar manner to stimuli occurring during seed development. Any kind of storage protein "operon" is clearly ruled out. We have observed other band patterns for convicilin than the three reported in this study in other pea lines, but this does not rule out the presence of further allelic forms at this locus. The Cvc locus appears to be identical to the vicilin locus designated VA or VcA by Thomson and Schroeder (1978), since this referred to a polypeptide of $\mathrm{Mr} 75,000$, and convicilin was present in the vicilin preparations of those authors. Variation in convicilin is shown in the vicilin type lines 3078 and 3080 (fig. 4) which show convicilin patterns similar to those of lines 1238 and 1263 respectively. Since convicilin is a storage protein distinct from the rest of the vicilin fraction (Croy et $a l,, 1980 c$ ), the VA designation for this locus is clearly invalid. The other vicilin loci identified by Thomson and Schroeder (VB, VC) were not considered in this study.

Acknowledgments. - We would like to acknowledge the help received from Dr S. Blixt, Weibullsholm, Sweden, who supplied seeds from pea lines and crosses and gave details of plant genotypes and phenotypes. Further, his advice was invaluable in assessing the results obtained in this work, which would not have been successfully carried out without his assistance. We also thank David Bown for technical assistance. N.K.M. acknowledges the receipt of a Commonwealth Scholarship.

\section{REFERENCES}

BLIXT, s. 1972. The pea. In King, R. S. (ed.) Handbook of Genetics, vol. 2, Plenum Press, New York, pp. 181-221.

BLIXT, S. 1977. The gene symbols of Pisum. Pisum New Letter 9, Supplement.

CASEY, R. 1979. Genetic variability in the structure of the $\alpha$-subunits of legumin from Pisum-a two-dimensional gel electrophoresis study. Heredity, 43, 265-272.

CASEY, R., AND SANGER, E. 1980. Purification and some properties of a 75 seed storage protein from Pisum (pea). Biochem. Soc. Trans., 8, 658.

CROY, R. R. D., DERBYSHIRE, E., KRISHNA, T. G., AND BOULTER, D. 1979. Legumin of Pisum sativum and Vicia faba. New Phytol., 83, 29-35.

CROY, R. R. D., GATEHOUSE, J. A., EVANS, I. M., AND BOULTER, D. 1980a. Characterisation of the storage protein subunits synthesised in vitro by polyribosomes and RNA from developing pea (Pisum sativum L). I. Legumin Planta, 148, 49-56. 
CROY, R. R. D., GATEHOUSE, J. A., EVANS, I. M., AND BOULTER, D. 1980b. Characterisation of the storage protein subunits synthesised in vitro by polyribosomes and RNA from developing pea (Pisum sativum L). II. Vicilin Planta, 148, 57-63.

CROY, R. R. D., GATEHOUSE, J. A., TYLER, M., AND BOULTER, D. 1980c. The purification and characterization of a third storage protein (convicilin) from the seeds of pea (Pisum sativum L). Biochem. J., 191, 509-516.

DAVIES, D. R. 1980. The ra locus and legumin synthesis in Pisum sativum. Biochem. Genet., $18,1207-1219$.

FISHER, R. A. 1925. Statistical Methods for Research Workers. Oliver and Boyd, Edinburgh.

GATEHOUSE, J, A., CROY, R. R. D., AND BOULTER, D. 1980. Isoelectric-focusing properties and carbohydrate content of pea (Pisum sativum) legumin. Biochem. J., 185, 497-503.

GATEhOuSE, J. A., CROY, R. R. D., MORTON, H., TYLER, M., AND BOUlTER, D. 1981. Characterisation and subunit structure of the vicilin storage proteins of pea (Pisum sativum L). Eur. J. Biochem., 118, 627-633.

HYNES, M. J. 1968. Genetically controlled variants of a storage protein in Pisum sativum. Aust. J. Biol. Sci., 21, 827-829.

IMMER, F. R. 1930. Formulae and table for calculating linkage intensities. Genetics, 15, 81-98.

LAEMMLI, U. K. 1970. Cleavage of structural proteins during the assembly of the head of bacteriophage $\mathrm{T}_{4}$. Nature (London), 227, 680-685.

MATTA, N. K., AND GATEhOUSE, J. A. 1981. Modification of the basic subunits of pea legumin on storage. Phytochemistry, 22, 2621-2623.

MATTA, N. K., GATEhOUSE, J. A., AND BOULTER, D. 1981a. The structure of legumin of Vicia faba L.-a reappraisal. J. Exp. Bot., 32, 182-197.

MATTA, N. K., GATEhouse, J. A., AND BOULTER, D. 1981b. Molecular and subunit heterogeneity of legumin of Pisum sativum L. (garden pea)-a multi-dimensional gel electrophoretic study. J. Exp. Bot., 32, 1295-1307.

THOMSON, J. A., AND SCHROEDER, H. E. 1978. Cotyledonary storage proteins in Pisum sativum. II. Hereditary variation in components of the legumin and vicilin fractions. Aust. J. Plant Physiol., 5, 281-294.

WRIGHT, D. J., AND BOULTER, D. 1974. Purification and subunit structure of legumin of Vicia faba L. (Broad bean). Biochem. J., 141, 413-418. 